\title{
Peace Values on Pancasila and Civic Education Textbooks in Senior High School
}

\author{
Diana Wulandari ${ }^{1}$, Mukhamad Murdiono ${ }^{2}$ \\ Pancasila and Civic Education \\ Yogyakarta State University \\ Yogyakarta, Indonesia \\ 1'diana.wulandari2016@student.uny.ac.id, ${ }^{2}$ mukhamad_murdiono@uny.ac.id
}

\begin{abstract}
The content of peace values on Pancasila and Civic Education Textbooks in Senior High School becomes very important and relevant to be examined. The peace values become an urgent need for learners and including the civic values within the framework of the civic education scope that learners must possess. The need to include the peace values requires textbooks. The purpose of this research is analyze peace values contained on Pancasila and Civic Education Textbooks in Senior High School. This research method using content analysis with qualitative approach. The object of this study is Pancasila and Civic Education textbooks in Senior High School which published by the Education and Culture Ministry that used in 2016/2017 academic year. Data collection technique through observation, recording, and analyzing with analysis sheets. The research procedures include data collection, data reduction, data analysis, and inference. The results show content of peace values on Pancasila and Civic Education textbooks in Senior High School consists of self-respect, respect with others, gender equality, respect for life/non-violence, compassion, global attention, ecological attention, cooperation, openness and tolerance, justice, social responsibility, and positive vision. These peace values reflect inner peace, social peace, and peace with nature.
\end{abstract}

Keywords-pancasila and civic education; peace values; textbooks

\section{INTRODUCTION}

The values of peace a strategic issue and urgent in the $21 \mathrm{st}$ century and the next period. A country will face a variety of internal and external issues that could potentially lead to conflict. Some conflicts can lead to acts of intolerance, violence, persecution, discrimination, hostility latent, etc. Various events are prone polarized conflict and divergent nature to many people, including students.

The values of peace become an important need to be continuously transmitted to the learner through education. In the countries of potential conflict, literature links between education and conflict has increased significantly with the same prevalence of the form of concern for education from the aspect of control, form and content of education [1]. Education is the best way to achieve peace [2]. Quality education is education that integrates the peace values in it [3]. Education is a vital tool to educate not only the intellectual academic, but also social and emotional transformation of learners [4]. Such education will produce learners who are prepared to become agents of academic, social and individual transformation agent [3].

The need to integrate the values of peace within the educational system requires the contents of the textbook [5], including civic education textbooks. The peace values and peace commitment into the scope of civic values and civic attitude in civic education curriculum [6]. During the period of transition to democracy, civic education textbooks in Spain includes the vision to achieve peace that is a state that is not only meant as a condition without war but also showing the condition of social equality and solidarity [7]. In European countries, civic education emphasizes social movements, human rights, and critical thinking [8]. The research results of Bromley's show that countries in Western Europe and North America have the highest human rights and diversity content in citizenship textbooks compared to countries in other regions [9].

In Indonesia, the discourse of citizenship in text books of civic education in the New Order era is very strong political interests of the ruler to construct citizens in order to have loyalty to the authorities. In post-reform, civic education textbook has undergone a transformation for strengthening democracy. However, the analysis content of peace values on Pancasila and Civic Education textbooks is important and relevant to control and improve textbooks. Furthermore, this research will analyze what are the peace values contained on Pancasila and Civic Education textbooks in Senior High School?

\section{THEORITICAL}

\section{A. Textbooks}

Textbooks can be defined as books written for learning purposes. Textbooks have a strategic position in the national curriculum and the learning of learners, even politically contributing. Textbooks are an important 'vehicle' for curriculum promotion [10]. Some research also shows that there is a relationship between political and ideological framing within the national curriculum that has a significant impact on the production and use of textbooks [11-13]. 
In learning, textbooks are the 'heart' of pedagogical activities [14]. Textbooks are intended not only to provide subjects knowledge but also the media to convey the universal and particular society values [4]. Textbooks can be called superior and can be used as "peace tools" if the textbook contains the peace values [15]. Textbooks have the potential to promote the peace values in explicitly and implicitly on every aspect of the textbook such as language, content, presentation or display, and illustrations [16]. Every level and field of study, textbooks and learning materials can be an important means of promoting peacemaking values such as human rights, nonviolent principles and practices, gender equality and nondiscrimination, reconciliation, mutual understanding and respect [17].

\section{B. Peace Values}

Peace values in terminology is derived from the value and peace. Value refers to the positive qualities intrinsic human [5]. Value is something good and idealized [18]. The concept of peace leads to two approaches, that is peace keeping and peace building [19]. Peace keeping related to the creation of negative peace in the form of absence of war, violence and physical cruelty. Peace building related to the creation of positive peace that includes inner peace, social peace, and peace with natural. Inner peace is a peace that arises from within, in harmony with oneself. Social peace is a peace that arises from human interaction, a peace that involves the harmony of human relations at all levels. Peace with nature views the importance of the earth as the cradle of human civilization, as well as efforts to create harmony with the natural environment [20]. Peace values is an positive qualities intrinsic of human good, valuable, useful, believed to be true and expected or aspired to build a total peace.

Castro \& Galace identify the values to teach peace include: self respect, respect with others, gender equality, respect for life/non-violence, compassion, global attention, ecological attention, cooperation, openness and tolerance, justice, social responsibility and positive vision [21]. Self-respect defined as having a sense of self-worth, a sense of pride in family, social and culture, standing by one's own strength, a sense of happiness and goodness that can contribute to positive change. Respect with others, which respect the dignity of others, including people of different social, religious, cultural and family backgrounds. Gender equality, which assesses the rights of women to enjoy equal opportunities with men and is free from torture or abuse, exploitation and violence. Respect life or non-violence, interpreted as a refusal to respond to enemies or situations of violent conflict; preferences for nonviolent processes such as collaborative problem-solving and other positive techniques without the use of physical force and weapons. Compassion, which is a form of sensitivity to the difficult conditions and suffering of others, acts with deep empathy, and goodness towards the marginalized. Global attention, that is to preserve the entire human community, concern and concern that transcends their own nation and state. Ecological attention is caring for the natural environment, preferences for sustainable living, and a simple lifestyle. Cooperation interpreted as a cooperative process and the principle of working together to pursue common goals.
Openness and tolerance defined as openness to the process of growth and change, the willingness to approach and accept ideas, beliefs and experiences of others, critical but open minds, respect for diversity. Justice is defined as acting with a sense of justice towards others, upholding the principle of equality (in dignity and rights), as well as the denial of all forms of exploitation and oppression. Social responsibility is a willingness to take action that contributes to the establishment of just society, nonviolence and welfare, as well as a sense of responsibility for present and future generations. Positive vision is to have a positive expectation in the future that is followed by good ways to realize hope.

\section{Pancasila and Civic Education}

The change of civic education to Pancasila and Civic Education in 2013 curriculum reflects a transformative movement. This nomenclature change is based on consideration of substance, competence, methodology, and judgment. This subject has characteristics: 1) the mission of characterizing the nationality and driving the character education, 2) complete and coherent integration of student competencies in core competencies, 3) scientific-based learning approaches, 4) the application of authentic assessment in the process and outcomes learning.

\section{METHOD}

This research uses content analysis with qualitative approach. This object research is the Pancasila and Civic Education textbooks on 2013 Curriculum in Senior High School grade 10, 11, and 12 published by the Education and Culture Ministry that used in 2016/2017. Data collection techniques is observation, recording, and analyzing with analysis sheet. Data analysis techniques is data collection, data reduction, data analysis, and inference.

\section{RESULT AND DISCUSSION}

Content of this object research indicate the existence of political and ideological framing that have a significant impact on the production and use of textbooks. The forms of political and ideological framing appear to emphasize: 1) Pancasila as the basic of the state, ideology, and worldview of the nation, 2) Constitution of Republic Indonesia, 3) the Unitary State of the Republic Indonesia as the final agreement of the form 4) Bhinneka Tunggal Ika as a manifestation of the philosophy of unity that underlies the diversity of life in society, nation and state. The content of the textbook emphasizes the formation of national identity such as the Indonesian symbols, Indonesian nationalism, homeland love, patriotism, state defense, unity, and the insight of the archipelago.

Pancasila and Civic Education textbooks on grade 10, 11, and 12 contained the peace values by means of explicit and implicit delivery. The findings of this research are relevant to the opinion of Jäger which states that in every level and field of study, textbooks can be an important means of promoting the values of peace [17]. National Council of Educational Research and Training states that textbooks have the potential to promote explicitly and implicitly of peace values in every aspect of the textbook such as language, content, presentation or display, 
including illustrations [16]. The peace values on Pancasila and Civic Education textbooks on grade 10, 11, and 12 consists of self-respect, respect with others, gender equality, non-violence promotion, compassion, global attention, ecological attention, cooperation, openness and tolerance, justice, social responsibility, and positive vision. The findings of this research show that the Pancasila and Civic Education textbooks on 2013 Curriculum in Senior High School grade 10, 11, and 12 reflects total peace that include inner peace, social peace, peace with nature.

Figure 1 shows the categorization of the peace values contained in the three textbooks.

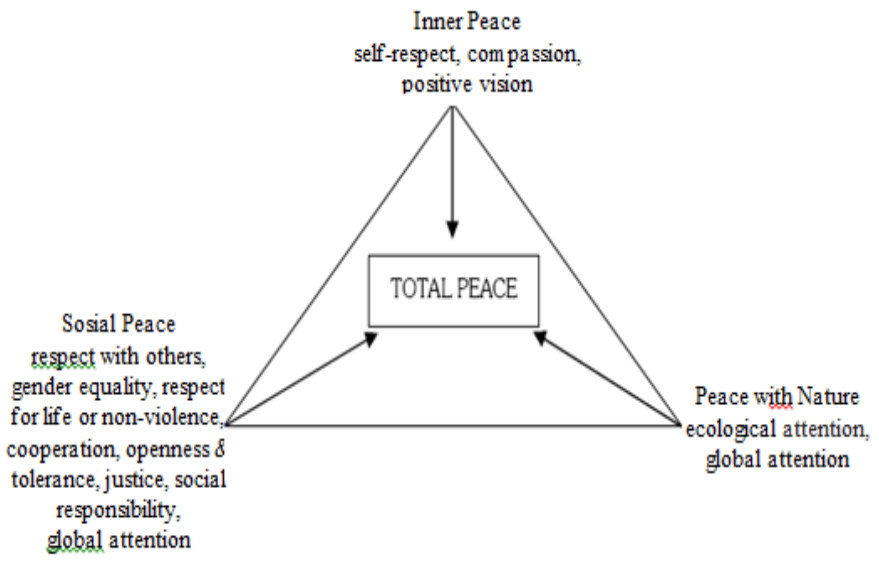

Fig. 1. Categorization of the peace values on pancasila and civic education textbooks in senior high school grade 10,11 , and 12 .

The values of self-respect, compassion, and positive vision are categorized as inner peace. Inner peace is a peace that arises from within, in harmony with oneself [20]. The value of respect with others, gender equality, respect for life or nonviolence, cooperation, openness \& tolerance, justice, social responsibility, global attention are categorized as social peace. Social peace is concerned with how to live with others. Social peace is a peace that arises from human interaction, a peace that involves the harmony of human relations at all levels [20]. The value of ecological attention and global attention are categorized as a peace with nature. Peace with nature views the importance of the earth as the cradle of human civilization as well as the effort to create harmony with the natural environment [20]. The peace values contained in the textbooks has levels ranging from personal peace, interpersonal, intergroup, interstate, to between humans with the earth and the natural environment.

Self-respect has a characteristic sense of value towards oneself that encourages to do good things that will enable themselves to contribute to positive change, including spiritual values that encourage individuals to do good and avoid bad behavior [21]. For example, "The relationship between man and God reflected in the first precepts can actually provide guidelines for not committing violations, especially when he has to commit corruption, misuse of state property, and other negative behaviors" (Pancasila and Civic Education textbooks in grade 10, pp. 23). Respect with others is a form of respect for the dignity of others without discriminating against the background [21]. For example, "Respect other people who are worshiping" (Pancasila and Civic Education textbooks in grade 11 , pp. 168). Gender equality deals with the recognition of women and equal opportunities with men, the strengthening of women's rights and women's empowerment. For example, "Government affairs in the context of sharpening, coordinating, and synchronizing government programs include women's empowerment, ..." (Pancasila and Civic Education textbooks in grade 10, pp. 14).

Respect for life (nonviolence) is a preference for nonviolent problem-solving processes, without the use of physical force and weapons [21]. For example, "Law enforcement officials must fulfill their obligations by providing good and fair service to the community, protecting everyone from unlawful acts, and avoiding unlawful acts of violence in order to enforce the law" (Pancasila and Civic Education textbooks in grade 12, pp. 132). The sentence explicitly includes non-violence values (avoiding unlawful acts of violence) and justice. Explicit and implicit discussion of justice value is often found in the three textbooks. Implicitly, the content of justice in textbooks can be a principle of equality, upholding human rights, and denial of exploitation, discrimination and oppression. Compassion is found in textbooks grade 11 and 12 in the form of harmonious, loving, and helpful. For example, "When you are at home, you can display a harmonious attitude through mutual respect and loving behavior with other family members," (Pancasila and Civic Education textbooks in grade 11, pp. 198).

Global attention is a value that indicates the concerns go beyond their own nation, including beyond the local or ethnic communities in the country concerned [21]. For example, a discourse entitled "Indonesia Continues Push for Peace and Reconstruction of Gaza" (Pancasila and Civic Education textbooks in grade 12, p.p 154-155). Ecologically attention is a form of preference for ecologically sustainable living to maintain and care for the natural environment [21]. For example, Pancasila and Civic Education textbooks in grade 10 (p.p 158) which implicitly contains ecological attention: "Along with the environmental issues and the impact of global warming raises serious issues that require international responses. Global warming has resulted in a change of the season uncertain that threaten human life in the form of threats of hunger, disease and natural disasters that could potentially disrupt economic stability and security".

Cooperation is defined as a cooperative process for a common goal [21]. Implicitly, cooperation can be seen in the form of the task group learning activities. The task group is always present in any textbook chapters on each textbook and intended for teamwork. Explicitly, cooperation also exist in the material in Pancasila and Civic Education textbooks in grade 10 (p.p 5): "... in the power-sharing mechanism, the state power is divided into several sections (legislative, executive and judicial), but not separated. This brings the consequence that between the parts it is possible there is no coordination or cooperation ".

Openness and tolerance is interpreted as a willingness to accept ideas, beliefs, experiences of others different from open and critical thoughts, respect and appreciate diversity [21]. For example, the content of Pancasila and Civic Education 
textbooks in grade 10 (pp. 60): "Harmony among religious people means the existence of understanding and unity to do deeds and religious teachings embraced with respect for the existence of differences that can still be tolerated. In other words, fellow believers are not allowed to be hostile, mutually humiliating, mutually overthrowing, but must develop mutual respect, respect and tolerance when there are differences, provided that the differences do not deviate from the religious teachings adopted. Harmony among religious people is a means to unite and strengthen the relationship between people who are not religious in the social interaction in society, but not intended to confuse religious teachings. This needs to be done to avoid the formation of dangerous extremism security, and public order. The real form that can be done is with the interreligious dialogue in which not discuss the differences, but to discuss harmony, and peace of life in the community. The point is that each religion teaches people to live in peace and tranquility ".

Social responsibility is a willingness to take action that contributes to establishment of just society, nonviolence and welfare [21]. For example, on a civic project in grade 12 (p.p 35): "Based on the data collected, try to make a poster that is loyal to the public to avoid acts that are potentially violating human rights". Positive vision is a positive hope in the future followed by good ways to realize hope [21]. For example in Pancasila and Civic Education textbooks in grade 11 (pp. 1): "Success depends greatly on your efforts, especially in overcoming the challenges and obstacles you face in grade 11 will get harder. Therefore, you must increase the quantity and quality of learning. Do not forget to always pray to God Almighty every time will start and end daily activities, including learning activities ".

\section{CONCLUSION}

Pancasila and Civic Education textbooks on grade 10, 11, and 12 contained the peace values by means of explicit and implicit delivery. The peace values on Pancasila and Civic Education textbooks on grade 10, 11, and 12 consists of selfrespect, respect with others, gender equality, non-violence promotion, compassion, global attention, ecological attention, cooperation, openness and tolerance, justice, social responsibility, and positive vision. The findings of this research show that the Pancasila and Civic Education textbooks on 2013 Curriculum in Senior High School grade 10, 11, and 12 reflects total peace that include inner peace, social peace, peace with nature.

\section{REFERENCES}

[1] A. Smith, "The influence of education on conflict and peace building," Education for all global monitoring report 2011. EFA Global Monitoring Report United Nations Educational, Scientific and Cultural, 2010.
[2] P.D. Baligadoo, "Peace profile: Maria Montessori-peace through education," Journal of Social Justice, vol. 26, no. (3), pp. 427-433, 2014.

[3] S. Gulati and D. Pant, Education for values in schools - A framework. New Delhi: National Council of Educational Researchand Training, 2013.

[4] M.Y. Gebregeorgis, "Peace values in language textbooks: The case of English for Ethiopia Student Textbook," Journal of Peace Education, pp. 1-15, 2016.

[5] United Nations Educational, Scientific and Cultural Organisation. Learning the way of peace teachers' guide to peace education. New Delhi: United Nations Educational, Scientific and Cultural Organisation, 2001.

[6] A. Doğanay, A curriculum framework for active democratic Civic education.M. Print and D. Lange. Schools, Curriculum and Civic Education forBuilding Democratic Citizens.Sense Publishers, 2012.

[7] K.M. Angulo, T. Groves, C.C.M. Barone, and Y.H. Laina, "Civic education and visions of war and peace in the Spanish transition to democracy," Paedagogica Historica, vol. 52, no. (1-2), pp. 169-187, 2016.

[8] H. Mintrop, "The old and new face of civic education: expert, teacher and student views," European Educational Research Journal, vol. 2, no. (3), pp. 446-454, 2003.

[9] P. Bromley, "Cosmopolitanism in civic education: exploring crossnational trends, 1970-2008," Current Issues in Comparative Education, vol. 12, no. (1), pp. 33-44, 2009.

[10] L. Okeeffe, “A Framework for textbook analysis," International Review of Contemporary Learning Research An International Journal, vol. 2, no. (1), pp. 1-13, 2013.

[11] G.A. Valverde, L.J. Bianchi, R.G. Wolfe, W.H. Schmidt, and R.T. Houang, According to the book: Using TIMSS to investigate the translation of policy into practice through the world of textbooks. London: Kluwer Academic Publishers, 2002.

[12] K. Crawford, "The role and purpose of textbooks," International Journal of Historical Learning, vol. 3, no. (2), pp. 5-10, 2003.

[13] F. Pingel, UNESCO Guidebook on textbook research and textbookrevision (2nd) revised and updated edition. Paris: United Nations Educational, Scientific and Cultural Organization, 2010.

[14] S. Kasmaienezhadfard, M. Pourrajab, and M. Rabbani, "Effects of pictures in textbooks on students' creativity," Multi Disciplinary Education Global Quest (Quarterly), vol. 4, no. (2), pp. 83-96, 2015.

[15] D. Georgescu, and J. Bernard, Thinking and building peace through innovative textbook design.Report of the inter-regional experts' meeting on developing guidelines for promoting peace andintercultural understanding through curricula, textbooks and learning materials. Paris: UNESCO, 2007.

[16] National Council of Educational Research and Training. National focus grouponeducation for peace. New Delhi: National Council of Educational Research and Training, 2006.

[17] U. Jäger, Peace education and conflict transformation (Hillary Crowe's translation). Berlin: Bergh of Foundation, 2014.

[18] K. Bertens, Etika. Yogyakarta: PT. Kanisius, 2013.

[19] J. Galtung, Peace by peaceful means: Peace and conflict, development and civilization. Oslo: International Peace Research Institute, 1996.

[20] United Nations Educational, Scientific and Cultural Organisation. Peace education framework for teacher education. New Delhi: United Nations Educational, Scientific and Cultural Organisation, 2005.

[21] L.N. Castro and N.G. Jasmin Peace education: A pathway to a culture of peace. Quezon City: Miriam College, 2010. 